\title{
Nutrient Uptake of Soybean (Glycine max L.) Plant as Affected by Liquid Biofertilizers (Bradyrhizobium and PSB)
}

\author{
Daravath Raja $^{1 *}$ and V. G. Takankhar ${ }^{2}$ \\ ${ }^{1}$ Department of Soil Science and Agricultural Chemistry, College of Agriculture, Latur, \\ V.N.M.K.V. Parbhani, India \\ ${ }^{2}$ Department of Soil Science and Agricultural Chemistry, Programme Coordinator, KVK, \\ Tuljapur, Dist-Osmanabad, V.N.M.K.V. Parbhani, India \\ *Corresponding author
}

A B S T R A C T

\begin{tabular}{|l|}
\hline K e y w o r d s \\
$\begin{array}{l}\text { Liquid Bio-fertilizers, } \\
\text { Bradyrhizobium, PSB, } \\
\text { Soybean, Nutrient uptake }\end{array}$ \\
\hline Article Info \\
\hline $\begin{array}{l}\text { Accepted: } \\
\text { 26 April } 2018 \\
\text { Available Online: } \\
\text { 10 May } 2018\end{array}$ \\
\hline
\end{tabular}

\section{Introduction}

Soybean (Glycine max) a leguminous crop originated in China. It is basically a pulse crop and gained the importance as an oil seed crop as it contains $20 \%$ cholesterol free oil. It posses a very high nutritional value, and contains 40 per cent high quality protein due to this reason, soybean is known as poor man's meat'. India stands next only to China in the Asia pacific region, with respect to production (12.9 m.t). Maharashtra is the second largest producer in India, with 4.86 m.t of production (Anonymous, 2013). Soybean played a key role in the yellow revolution. It is newly introduced and commercially exploited crop in India. Soybean has been playing an important role in national economy by earning an average of Rs. 32,000 million per annum through export of soy meal and contributing about $18 \%$ to the edible oil production (Anonymous, 2012).

The prices of fertilizers are increasing day by day and therefore, it is necessary to reduce the cost of fertilizers by using Bradyrhizobium and PSB inoculation to increase yield of legume crops. Biofertilizers cannot replace chemical fertilizers, but certainly are capable of reducing their input. Seed inoculation with 
effective Bradyrhizobium inoculant is recommended to ensure adequate nodulation and $\mathrm{N}_{2}$ fixation for maximum growth and yield of pulse crop. Biofertilizer do not supply nutrients directly to crop plants but have capacity to fix atmospheric nitrogen and convert insoluble phosphate into soluble form. Hence, soil microorganisms play significant role in mobilizing $\mathrm{P}$ for the use of plant and large fraction of soil microbial population can dissolve insoluble phosphate in soil. Zarrin et al., (2007) studied the interactive effect of Rhizobium strains and $\mathrm{P}$ on soybean yield, Nitrogen fixation and soil fertility and observed the mixed Rhizobium inoculation with as well as without phosphorus significantly increased N P K uptake in shoot of soybean as compared to control.

\section{Materials and Methods}

The field experiment was conducted in Kharif season during the year 2013-14 at the research farm of Oil Seed Research Station, Latur, Maharashtra, geographically situated between $18^{0} 05^{\prime}$ to $18^{0} 75^{\prime} \mathrm{N}$ latitude and between $76^{\circ}$ $25^{\prime}$ to $77^{0} 36^{\prime} \mathrm{E}$ longitude on the Deccan plateau with height mean sea level (MSL) about 633.85 meters and average rainfall is $750-800 \mathrm{~mm}$. The experimental soil was deep black in color with good drainage, moderate calcareous in nature and moderate alkaline in reaction with $\mathrm{pH}(1: 2.5)$ 8.30, EC (1:2.5) 0.36 $\mathrm{dSm}^{-1} \mathrm{CaCO}_{3}(5.03 \%)$ and organic $\mathrm{C}\left(5.4 \mathrm{~g} \mathrm{~kg}^{-}\right.$ $\left.{ }^{1}\right)$ The available soil $\mathrm{N}, \mathrm{P}, \mathrm{K}$ and $\mathrm{S}$ were 131.20, 19.68, 597.9, $15.35 \mathrm{kgha}^{-1}$ respectively. Soybean was grown in factorial randomized block design with three replications and variety MAUS-81 as a test crop along with 16 treatment combination containing four levels of liquid Bradyrhizobium (0ml, 5ml, 10ml, and 15ml) and four levels of liquid PSB $(0 \mathrm{ml}, 5 \mathrm{ml}, 10 \mathrm{ml}$, and $15 \mathrm{ml}$ ). Soybean seed after inoculation with required quantity of liquid biofertilizers viz. Bradyrhizobium and PSB was sown at spacing $45 \times 5 \mathrm{~cm} @ 75 \mathrm{~kg} \mathrm{ha}^{-1}$ in 4th July, 2013. A uniform dose of fertilizers (30:60:30:30 kg ha ${ }^{-1}$ of $\mathrm{N}, \mathrm{P}_{2} \mathrm{O}_{5}, \mathrm{~K}_{2} \mathrm{O}, \mathrm{S}$ ) were supplied through urea, SSP, MOP and bensulph before sowing. Hand weeding was carried out at 26 DAS first spray of Chloropyriphos $25 \mathrm{ml} / 10$ lit water, bavistin 20 $\mathrm{gm} / 10$ lit water at time of incidence of insect pests (30DAS) and second of proclaim (benzoet) $15 \mathrm{gm} / 10$ lit of water at in 30 days interval of first spray. The crop was harvested on 15 Oct. 2013.

\section{Results and Discussion}

\section{Uptake of nutrients}

In order to study the impact of different levels of liquid Bradyrhizobium and PSB on nutrient uptake in soybean, plant samples were analyzed for $\mathrm{N}, \mathrm{P}, \mathrm{K}$ and $\mathrm{S}$ and result presented here.

\section{Nitrogen uptake}

In order to study the impact of different levels of liquid Bradyrhizobium and PSB on nutrient uptake in soybean, plant samples were analyzed for $\mathrm{N}, \mathrm{P}, \mathrm{K}$ and $\mathrm{S}$ and result presented here.

The $\mathrm{N}$ uptake in soybean plant was significantly influenced by liquid Bradyrhizobium at all the growth stages. Significantly higher $\mathrm{N}$ uptake was observed with $\mathrm{A}_{2}-10 \mathrm{ml}$ of Bradyrhizobium japonicum $\mathrm{kg}^{-1}$ seed treatment at branching $\left(43.92 \mathrm{~kg} \mathrm{ha}^{-}\right.$ $\left.{ }^{1}\right)$, flowering (59.30 kg ha $\left.{ }^{-1}\right)$, pod formation $\left(77.05 \mathrm{~kg} \mathrm{ha}^{-1}\right)$, maturity $\left(96.42 \mathrm{~kg} \mathrm{ha}^{-1}\right)$ and at harvest $\left(80.54 \mathrm{~kg} \mathrm{ha}^{-1}\right)$ over $\mathrm{A}_{0}$ and $\mathrm{A}_{1}$ treatments. Treatments $\mathrm{A}_{0}$ (control) and $\mathrm{A}_{1}$ (5ml Bradyrhizobium japonicum $\mathrm{kg}^{-1}$ seed) as well as $\mathrm{A}_{2}$ (10ml Bradyrhizobium japonicum $\mathrm{kg}^{-1}$ seed) and $\mathrm{A}_{3}$ (15ml Bradyrhizobium japonicum $\mathrm{kg}^{-1}$ seed) were at par with each other at all the growth stages of soybean. 
Significantly lower $\mathrm{N}$ uptake was recorded with treatment $\mathrm{A}_{0}$ (control). Sheerin et al., (1998) showed that application of $\mathrm{N}$ fixing biofertilizers enhances the organic acids which may partly be responsible for quick release of nutrients, resulting in more uptakes of nutrients. These results substantiated the findings of Kumrawat et al., (1997). Further Chandra (2006) observed application of $20 \mathrm{~g}$ Rhizobium $\mathrm{kg}^{-1}$ indicated statistically similar $\mathrm{N}$ accumulation in grain $\left(42.5 \mathrm{~kg} \mathrm{ha}^{-1}\right)$ and more $\mathrm{N}$ uptake by straw $\left(18.4 \mathrm{~kg} \mathrm{ha}^{-1}\right)$ than the uninoculated control. The higher (i.e., $40 \mathrm{~g} \mathrm{~kg}^{-}$ ${ }^{1}$ seed) inoculums rate recorded significantly higher $\mathrm{N}$ uptake by grain $\left(45.4 \mathrm{~kg} \mathrm{ha}^{-1}\right)$ and straw (19.8 kg ha $\left.{ }^{-1}\right)$ than the uninoculated (control). The $\mathrm{N}$ uptake in soybean plant was significantly influenced by liquid PSB levels at all the growth stages of soybean except branching and flowering stage (Table 1). Significantly higher $\mathrm{N}$ uptake was observed with $\mathrm{B}_{2}\left(10 \mathrm{ml}\right.$ of PSB kg${ }^{-1}$ seed) treatment at pod formation $\left(75.01 \mathrm{~kg} \mathrm{ha}^{-1}\right)$, maturity $(95.56$ $\mathrm{kg} \mathrm{ha}^{-1}$ ) and harvest stage (79.75 $\mathrm{kg} \mathrm{ha}^{-1}$ ) over $\mathrm{B}_{0}$ and $\mathrm{B}_{1}$ treatments but treatments $\mathrm{B}_{0}$ (control) and $\mathrm{B}_{1}\left(5 \mathrm{ml} \mathrm{PSB} \mathrm{kg}{ }^{-1}\right.$ seed) as well as $B_{2}\left(10 \mathrm{ml} \mathrm{PSB} \mathrm{kg}^{-1}\right.$ seed) and $\mathrm{B}_{3}$ (15ml PSB $\mathrm{kg}^{-1}$ seed) were were at par with each other at all the pod formation, maturity and harvest growth stages of soybean. Significantly lower $\mathrm{N}$ uptake was recorded with treatment $\mathrm{B}_{0}$ (control). Single inoculation of Azotobacter failed to improve the uptake of $\mathrm{N}$ and $\mathrm{P}$, but inoculation of soybean with Rhizobium, PSB and FYM markedly improved their uptake (Krishna Reddy et al., 2007).

The interaction effect between liquid Bradyrhizobium and PSB $(\mathrm{A} \times \mathrm{B})$ on $\mathrm{N}$ uptake in soybean was not significant. The treatment $\mathrm{A}_{2} \mathrm{~B}_{2}$ was not significant but it gave maximum $\mathrm{N}$ uptake at all the growth stages of soybean crop. However dual as well as multi inoculation of biofertilizers with or without FYM statistically increased the uptake of $\mathrm{N}$ and $\mathrm{P}$. This might be attributed to enhanced activity of nitrogenase and nitrate-reductase enzyme in the soil (Oad et al., 2002).

\section{Uptake of phosphorus}

The $\mathrm{P}$ uptake in soybean was significantly influenced by liquid Bradyrhizobium levels at all the growth stages of soybean except branching and flowering stage (Table 2). At branching and flowering stage results with respect to $\mathrm{P}$ uptake were non-significant. Significantly higher $\mathrm{P}$ uptake observed with $\mathrm{A}_{2}$ (10ml of Bradyrhizobium $\mathrm{kg}^{-1}$ seed) treatment at pod formation (14.21 kg ha-1), maturity (16.65 kg ha-1) and at harvest (13.83 $\mathrm{kg} \mathrm{ha}{ }^{-1}$ ) over $A_{0}$ and $A_{1}$ treatments but treatments $A_{0}$ (control) and $A_{1}\left(5 \mathrm{ml} \mathrm{PSB} \mathrm{kg}^{-1}\right.$ seed) as well as $\mathrm{A}_{2}\left(10 \mathrm{ml} \mathrm{PSB} \mathrm{kg}{ }^{-1}\right.$ seed) and $\mathrm{A}_{3}\left(15 \mathrm{ml} \mathrm{PSB} \mathrm{kg}{ }^{-1}\right.$ seed) were at par with each other at all the pod formation, maturity and harvest growth stages of soybean. Significantly lower $\mathrm{P}$ uptake was recorded with treatment $\mathrm{A}_{0}$ (control).

The $\mathrm{P}$ uptake in soybean plant was significantly influenced by liquid PSB levels at all the growth stages. Significantly higher $p$ uptake observed with $\mathrm{B}_{2^{-}} 10 \mathrm{ml}$ of PSB kg-1 seed treatment at branching (7.95 kg ha-1), flowering $\left(11.21 \mathrm{~kg} \mathrm{ha}^{-1}\right)$, pod formation $\left(13.80 \mathrm{~kg} \mathrm{ha}^{-1}\right)$, maturity $\left(17.71 \mathrm{~kg} \mathrm{ha}^{-1}\right)$ and at harvest $\left(14.77 \mathrm{~kg} \mathrm{ha}^{-1}\right)$ over $\mathrm{B}_{0}$ and $\mathrm{B}_{1}$ treatments at all the growth stages but treatments $\mathrm{B}_{0}$ (control) and $\mathrm{B}_{1}(5 \mathrm{ml}$ PSB kg-1 seed) as well as $B_{2}\left(10 \mathrm{ml} \mathrm{PSB} \mathrm{kg}^{-1}\right.$ seed) and

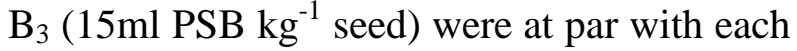
other at all the growth stages of soybean. Significantly lower $\mathrm{P}$ uptake was recorded with treatment $\mathrm{B}_{0}$ (control).

The higher concentration of phosphorus at branching might be due to the ability of PSB to transform insoluble phosphate in soil in to soluble forms by screating organic acids resulting in effective solubilization and utilization of phosphate. 
Table.1 Effect of liquid bio-fertilizers on $\mathrm{N}$ uptake at various critical growth stages of soybean

\begin{tabular}{|c|c|c|c|c|c|}
\hline \multirow[t]{2}{*}{ Treatments } & \multicolumn{5}{|c|}{ N uptake $\left(\mathrm{kg} \mathrm{ha}^{-1}\right)$} \\
\hline & branching & flowering & pod formation & maturity & harvest \\
\hline \multicolumn{6}{|c|}{ Rhizobium levels (A) } \\
\hline $\mathrm{A}_{0}(0 \mathrm{ml})$ & 38.14 & 51.47 & 65.38 & 86.41 & 71.31 \\
\hline $\mathrm{A}_{1}(5 \mathrm{ml})$ & 39.42 & 53.43 & 68.42 & 88.72 & 73.44 \\
\hline $\mathrm{A}_{2}(10 \mathrm{ml})$ & 43.92 & 59.30 & 77.05 & 96.42 & 80.54 \\
\hline $\mathrm{A}_{3}(15 \mathrm{ml})$ & 41.93 & 56.13 & 72.25 & 92.07 & 77.93 \\
\hline S.Em \pm & 1.05 & 1.58 & 2.21 & 1.48 & 1.38 \\
\hline $\mathrm{CD}$ at $5 \%$ & 3.05 & 4.58 & 6.38 & 4.29 & 4.01 \\
\hline \multicolumn{6}{|l|}{ PSB levels (B) } \\
\hline $\mathrm{B}_{0}(0 \mathrm{ml})$ & 38.49 & 52.32 & 66.53 & 86.84 & 71.70 \\
\hline $\mathrm{B}_{1}(5 \mathrm{ml})$ & 39.62 & 53.85 & 68.92 & 89.40 & 74.07 \\
\hline $\mathrm{B}_{2}(10 \mathrm{ml})$ & 43.19 & 57.84 & 75.01 & 95.56 & 79.75 \\
\hline $\mathrm{B}_{3}(15 \mathrm{ml})$ & 42.12 & 56.35 & 72.64 & 91.85 & 77.72 \\
\hline S.Em \pm & 1.05 & 1.58 & 2.21 & 1.48 & 1.38 \\
\hline $\mathrm{CD}$ at $5 \%$ & NS & NS & 6.38 & 4.29 & 4.01 \\
\hline \multicolumn{6}{|c|}{ Interaction $(\mathbf{A} \times \mathbf{B})$} \\
\hline S.Em \pm & 2.11 & 3.17 & 4.42 & 2.97 & 2.77 \\
\hline CD at 5\% & NS & NS & NS & NS & NS \\
\hline
\end{tabular}


Table.2 Effect of liquid bio-fertilizers on P uptake at various critical growth stages of soybean
Treatments
P uptake (kg ha-1)

\begin{tabular}{|l|l|l|l|r|}
\hline Branching & Flowering & Pod formation & Maturity & Harvest \\
\hline
\end{tabular}

Rhizobium levels (A)

\begin{tabular}{|c|c|c|c|c|c|}
\hline $\mathrm{A}_{0}(0 \mathrm{ml})$ & 6.99 & 9.97 & 11.97 & 12.80 & 10.37 \\
\hline $\mathrm{A}_{1}(5 \mathrm{ml})$ & 7.25 & 10.37 & 12.57 & 13.98 & 11.41 \\
\hline $\mathrm{A}_{2}(10 \mathrm{ml})$ & 8.10 & 11.51 & 14.21 & 16.65 & 13.83 \\
\hline $\mathrm{A}_{3}(15 \mathrm{ml})$ & 7.71 & 10.88 & 13.28 & 15.80 & 13.05 \\
\hline S.Em \pm & 0.20 & 0.31 & 0.42 & 0.81 & 0.72 \\
\hline $\mathrm{CD}$ at 5\% & $\mathrm{NS}$ & $\mathrm{NS}$ & 1.22 & 2.34 & 2.09 \\
\hline PSB levels $(\mathbf{B})$ & & & & & \\
\hline $\mathrm{B}_{0}(0 \mathrm{ml})$ & 7.05 & 10.12 & 12.18 & 12.72 & 10.30 \\
\hline $\mathrm{B}_{1}(5 \mathrm{ml})$ & 7.29 & 10.45 & 12.68 & 13.64 & 11.12 \\
\hline $\mathrm{B}_{2}(10 \mathrm{ml})$ & 7.95 & 11.21 & 13.80 & 17.71 & 14.77 \\
\hline $\mathrm{B}_{3}(15 \mathrm{ml})$ & 7.96 & 10.94 & 13.39 & 15.17 & 12.49 \\
\hline S.Em \pm & 0.20 & 0.31 & 0.42 & 0.81 & 0.72 \\
\hline CD at 5\% & 0.58 & 0.88 & 1.22 & 2.34 & 2.09 \\
\hline Interaction (A×B) & & & & & \\
\hline S.Em \pm & 0.40 & 0.62 & 0.84 & 1.62 & 1.44 \\
\hline CD at 5\% & NS & NS & NS & NS & \\
\hline
\end{tabular}


Table.3 Influence of liquid bio-fertilizers on $\mathrm{K}$ uptake at various critical growth stages of soybean

\section{\begin{tabular}{|l|l|l|l|l|}
\hline Branching & Flowering & Pod formation & Maturity & Harvest
\end{tabular}}

\section{Rhizobium levels (A)}

\begin{tabular}{|c|c|c|c|c|r|}
\hline $\mathrm{A}_{0}(\mathrm{Oml})$ & 33.34 & 43.33 & 45.39 & 54.79 & 43.67 \\
\hline $\mathrm{A}_{1}(5 \mathrm{ml})$ & 34.58 & 45.22 & 48.10 & 58.12 & 46.63 \\
\hline $\mathrm{A}_{2}(10 \mathrm{ml})$ & 38.80 & 50.68 & 55.46 & 67.34 & 54.90 \\
\hline $\mathrm{A}_{3}(15 \mathrm{ml})$ & 36.94 & 47.79 & 51.54 & 63.62 & 51.56 \\
\hline $\mathrm{S} . \mathrm{Em} \pm$ & 1.02 & 1.53 & 2.02 & 2.51 & 2.24 \\
\hline $\mathrm{CD}$ at $5 \%$ & 2.94 & 4.42 & 7.26 & 4.29 & 6.46 \\
\hline
\end{tabular}

\section{PSB levels (B)}

\begin{tabular}{|c|c|c|c|c|c|}
\hline $\mathrm{B}_{0}(0 \mathrm{ml})$ & 33.72 & 44.18 & 46.56 & 56.17 & 44.90 \\
\hline $\mathrm{B}_{1}(5 \mathrm{ml})$ & 34.79 & 45.63 & 48.61 & 59.56 & 47.92 \\
\hline $\mathrm{B}_{2}(10 \mathrm{ml})$ & 38.06 & 49.26 & 53.57 & 64.96 & 52.77 \\
\hline $\mathrm{B}_{3}(15 \mathrm{ml})$ & 37.10 & 47.95 & 51.76 & 63.18 & 51.17 \\
\hline S.Em \pm & 1.02 & 1.53 & 2.02 & 2.51 & 2.24 \\
\hline $\mathrm{CD}$ at $5 \%$ & 2.94 & NS & NS & NS & NS \\
\hline \multicolumn{6}{|c|}{ Interaction $(\mathbf{A} \times \mathbf{B})$} \\
\hline S.Em \pm & 2.04 & 3.06 & 4.04 & 5.03 & 4.47 \\
\hline CD at $5 \%$ & NS & NS & NS & NS & NS \\
\hline
\end{tabular}


Table.4 Effect of liquid bio-fertilizers on S uptake at various critical growth stages of soybean
Treatments
S uptake $\left(\mathrm{kg} \mathrm{ha}^{-1}\right)$

Branching

Flowering

Pod formation

Maturity

Harvest

Rhizobium levels (A)

\begin{tabular}{|c|c|c|c|c|c|}
\hline $\mathrm{A}_{0}(0 \mathrm{ml})$ & 6.43 & 9.12 & 10.57 & 12.60 & 10.51 \\
\hline $\mathrm{A}_{1}(5 \mathrm{ml})$ & 6.68 & 9.50 & 11.14 & 13.30 & 11.14 \\
\hline $\mathrm{A}_{2}(10 \mathrm{ml})$ & 7.49 & 10.60 & 12.68 & 15.22 & 12.90 \\
\hline $\mathrm{A}_{3}(15 \mathrm{ml})$ & 7.13 & 10.00 & 11.82 & 14.42 & 12.16 \\
\hline $\mathrm{S} . \mathrm{Em} \pm$ & 0.20 & 0.30 & 0.41 & 0.50 & 0.45 \\
\hline $\mathrm{CD}$ at $5 \%$ & 0.57 & 0.87 & 1.18 & 1.46 & 1.31 \\
\hline
\end{tabular}

PSB levels (B)

\begin{tabular}{|c|c|c|c|c|c|}
\hline $\mathrm{B}_{0}(0 \mathrm{ml})$ & 6.49 & 9.26 & 10.77 & 12.83 & 10.72 \\
\hline $\mathrm{B}_{1}(5 \mathrm{ml})$ & 6.72 & 9.59 & 11.25 & 13.60 & 11.41 \\
\hline $\mathrm{B}_{2}(10 \mathrm{ml})$ & 7.35 & 10.31 & 12.29 & 14.73 & 12.46 \\
\hline $\mathrm{B}_{3}(15 \mathrm{ml})$ & 7.17 & 10.06 & 11.92 & 14.37 & 12.12 \\
\hline S.Em \pm & 0.20 & 0.30 & 0.41 & 0.50 & 0.45 \\
\hline CD at 5\% & 0.57 & $\mathrm{NS}$ & $\mathrm{NS}$ & $\mathrm{NS}$ & $\mathrm{NS}$ \\
\hline Interaction $(\mathbf{A} \times \mathbf{B})$ & & & & & \\
\hline S.Em \pm & 0.40 & 0.60 & 0.82 & 1.01 & 0.90 \\
\hline CD at 5\% & NS & NS & NS & NS & NS \\
\hline
\end{tabular}


Inoculation of PSB alone increased the concentration of phosphorus in plant. Dubey (1997) found that phosphate solubilizing microorganisms play a major role in the solubilization and uptake of native and applied soil phosphorus.

The interaction effect between liquid Bradyrhizobium and PSB $(\mathrm{A} \times \mathrm{B})$ on $\mathrm{P}$ uptake in soybean plant was non-significant. The combined treatment $\mathrm{A}_{2} \mathrm{~B}_{2} \quad(10 \mathrm{ml}$ of Bradyrhizobium $+10 \mathrm{ml} \mathrm{PSB} \mathrm{kg}{ }^{-1}$ seed) gave maximum $\mathrm{P}$ uptake at all the growth stages of soybean crop.

However dual as well as multi inoculation of biofertilizers with or without FYM statistically increased the uptake of $\mathrm{N}$ and $\mathrm{P}$. This might be attributed to enhanced activity of nitrogenase and nitrate-reductase enzyme in the soil (Purbey and Sen 2007), leading to greater biological nitrogen fixation by Rhizobium and increased availability of $\mathrm{P}$ in the soil due to greater solubilization of phosphate compound by phosphate solubilizing bacteria.

\section{Uptake of potassium}

The $\mathrm{K}$ uptake in soybean plant was significantly influenced by liquid Bradyrhizobium levels at all the growth stages of soybean (Table 3 ).

Significantly higher $\mathrm{K}$ uptake was recorded with $\mathrm{A}_{2}$ (10ml of Bradyrhizobium $\mathrm{kg}^{-1}$ seed) treatment at branching $\left(38.80 \mathrm{~kg} \mathrm{ha}^{-1}\right)$, flowering (50.68 $\left.\mathrm{kg} \mathrm{ha}^{-1}\right)$, pod formation $\left(55.46 \mathrm{~kg} \mathrm{ha}^{-1}\right)$, maturity $\left(67.34 \mathrm{~kg} \mathrm{ha}^{-1}\right)$ and at harvest $\left(54.90 \mathrm{~kg} \mathrm{ha}^{-1}\right)$ over $\mathrm{A}_{0}$ and $\mathrm{A}_{1}$ treatments. The treatments $\mathrm{A}_{0}$ (control) and $\mathrm{A}_{1}\left(5 \mathrm{ml}\right.$ Bradyrhizobium $\mathrm{kg}^{-1}$ seed) as well as $\mathrm{A}_{2}$ (10ml Bradyrhizobium kg-1 seed) and $\mathrm{A}_{3}$ (15ml Bradyrhizobium $\mathrm{kg}^{-1}$ seed) were at par with each other at all the growth stages of soybean. Significantly lower K uptake was recorded with treatment $A_{0}$ (control). Similar results were found in $\mathrm{K}$ uptake by Kapure and Naik (2004) and Thenua et al., (2006).

The data indicated that the difference in $\mathrm{K}$ uptake due to different liquid PSB levels were not reach to the level of significance except branching stage. Maximum and minimum $\mathrm{K}$ uptake (Table 3$)$ was recorded with $\mathrm{B}_{2}(10 \mathrm{ml}$ PSB $\mathrm{kg}^{-1}$ seed) and $\mathrm{B}_{0}$ (control) at all the growth stages of soybean.

Significantly higher K uptake observed with $B_{2}(10 \mathrm{ml}$ of PSB kg-1 seed) treatment at branching (38.06 kg ha ${ }^{-1}$ ) over $\mathrm{B}_{0}$ and $\mathrm{B}_{1}$ treatments but treatments $\mathrm{B}_{0}$ (control) and $\mathrm{B}_{1}$ (5ml PSB kg${ }^{-1}$ seed) as well as $\mathrm{B}_{2}(10 \mathrm{ml}$ PSB $\mathrm{kg}^{-1}$ seed) and $\mathrm{B}_{3}\left(15 \mathrm{ml}\right.$ PSB kg${ }^{-1}$ seed) found on par with each other. Significantly lower P uptake was recorded with treatment $\mathrm{B}_{0}$ (control).

Deshmukh et al., (2005) studied the effect of integrated use of inorganic, organic and biofertilizers on production, nutrient availability and economic feasibility of soybean grown on soil of kaymore plateau and satpura hills and reported that the application of $75 \%$ NPK + FYM + PSB significantly increased the uptake of N, P and $\mathrm{K}$ by 109.9, 20.9 and 106.4 per cent over farmer's practice.

The interaction effect between liquid Bradyrhizobium and PSB $(\mathrm{A} \times \mathrm{B})$ on $\mathrm{K}$ uptake in soybean plant was failed to reach the levels of significance. The combined treatment $\mathrm{A}_{2} \mathrm{~B}_{2}$ (10ml of Bradyrhizobium $+10 \mathrm{ml}$ PSB kg-1 seed) was not significant but it gave maximum $\mathrm{K}$ uptake at all the growth stages of soybean crop.

Disintegration of $\mathrm{K}$ minerals due to release of organic acids by bioinoculants used for seed inoculation purpose. It was also noticed that dual inoculation of Rhizobium + PSB showed its superiority over single inoculation of PSB and Rhizobium. These results are in line with 
the finding of Sharma and Namdeo (1999) found seed inoculation with Rhizobium and PSB in presence of FYM gave higher $\mathrm{N}, \mathrm{P}$ and $\mathrm{K}$ contents in plant and seed.

\section{Uptake of sulphur}

Data indicating uptake of sulphur recorded at branching, flowering, pod formation, maturity and at harvest was presented in Table 4. It was evident from the results that the sulphur uptake was significantly influenced by individual seed treatment with Bradyrhizobium and PSB levels.

Significantly higher S uptake recorded with $\mathrm{A}_{2}$ (10ml of Bradyrhizobium $\mathrm{kg}^{-1}$ seed) treatment at branching $\left(7.49 \mathrm{~kg} \mathrm{ha}^{-1}\right)$, flowering (10.60 $\left.\mathrm{kg} \mathrm{ha}^{-1}\right)$, pod formation (12.68 $\left.\mathrm{kg} \mathrm{ha}^{-1}\right)$, maturity $\left(15.22 \mathrm{~kg} \mathrm{ha}^{-1}\right)$ and at harvest $\left(12.90 \mathrm{~kg} \mathrm{ha}^{-1}\right)$ over $\mathrm{A}_{0}$ and $\mathrm{A}_{1}$ treatments.

The treatments $A_{0}$ (control) and $A_{1}(5 \mathrm{ml}$ Bradyrhizobium $\mathrm{kg}^{-1}$ seed) as well as $\mathrm{A}_{2}$ (10ml Bradyrhizobium $\mathrm{kg}^{-1}$ seed) and $\mathrm{A}_{3}$ (15ml Bradyrhizobium $\mathrm{kg}^{-1}$ seed) were at par with each other at all the growth stages of soybean. Significantly lower S uptake was recorded with treatment $\mathrm{A}_{0}$ (control). Increased uptake of $\mathrm{S}$ by Rhizobium in soybean crop might be due to higher concentration of $S$ in plant and increased dry matter yield of soybean crop. The higher content of $\mathrm{S}$ in seed and straw together with increased seed and straw yield might be the result of greater uptake of sulphur. These results are in agreement with those of Tomar (2011).

The data indicated that the difference in $S$ uptake due to different liquid PSB levels was significantly affected at branching stage only. The treatment $\mathrm{B}_{2}\left(10 \mathrm{ml}\right.$ of PSB kg${ }^{-1}$ seed) recorded significantly higher $S$ uptake at branching (7.49 kg ha ${ }^{-1}$ ) over $\mathrm{B}_{0}$ and $\mathrm{B}_{1}$ treatments but treatments $\mathrm{B}_{0}$ (control) and $\mathrm{B}_{1}$ (5ml PSB kg-1 seed) as well as $\mathrm{B}_{2}(10 \mathrm{ml}$ PSB $\mathrm{kg}^{-1}$ seed) and $\mathrm{B}_{3}\left(15 \mathrm{ml}\right.$ PSB kg${ }^{-1}$ seed) were at par with each other. Significantly lower $S$ uptake was recorded with treatment $B_{0}$ (control). The result indicated that the difference in $S$ uptake due to different liquid PSB levels were not reach to the level of significance except branching stage. The higher $S$ uptake was recorded under the treatment $\mathrm{B}_{2}(10 \mathrm{ml}$ of PSB kg-1 seed) and lower $\mathrm{S}$ uptake was observed with $\mathrm{B}_{0}$ (control) treatment at all the growth stages of soybean except branching stage.

Pratibha and Ramesh (2011) studied the performance of liquid and carrier-based inoculats of Mesorhizobium ciceri and PGPR (Pseudomonas diminuta) in Chickpea (Cicer arietinum L.) on nodulation yield and soil properties and reported that the liquid inoculant of PGPR recorded significantly more $S$ uptake by grain and straw by 6.7 and $19.4 \%$ respectively than its carrier-based inoculants. Similar finding were recorded by Khandelwal et al., (2012).

The interaction effect between liquid Bradyrhizobium and PSB $(\mathrm{A} \times \mathrm{B})$ on $\mathrm{S}$ concentration and uptake in soybean was failed to reach the levels of significance. The treatment $\mathrm{A}_{2} \mathrm{~B}_{2}$ (10ml of Bradyrhizobium +

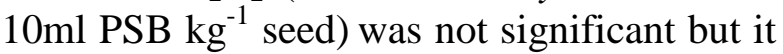
gave maximum $\mathrm{S}$ content and uptake at all the growth stages of soybean crop.

\section{References}

Anonymous (2012). Soybean basic introduction. w.w.w.pnbkrishi.com/soybean.htm.

Anonymous (2013). Soybean Processors Association of India.w.w.w.sopa.org.

Chandra, R. (2006) Rhizobium inoculation in urdbean and its residual effect on 
wheat. Indian J. Pulses Res., 19 (2): 213-215

Deshmukh, K.K, Khatik, S.K. and Dubey, D.P. (2005). Effect of integrated use of inorganic, organic and biofertilizers on production, nutrient availability and economic feasibility of soybean grown on soil of kaymore plateau and satpura hills. J. Soils and Crops, 15 (1): 21-25.

Dubey, S.K. (1997). Co-inoculation of phosphorus solubilizing bacteria with Bradyrhizobium japonicum to increase phosphate availability to rainfed soybean on Vertisol. J. Indian Soc. Soil Sci., 45 (3):506-509.

Kapure, R.M. and Naik, R.M. (2004). Effect of biofertilizers on $\mathrm{N}, \mathrm{P}$ contents of leaves, available $\mathrm{P}$ from soil, legheamoglobin and chlorophyll content in chickpea. J. Soils and Crops, 14 (1): 22-25.

Khandelwal, R., Choudhary, S.K., Khangarot, S.S., Jat, M.K. and Singh, P. (2012). Effect of inorganic and bio-fertilizers on productivity and nutrients uptake in cowpea (Vigna unguiculata). J. Food Legume Res. 35 (3): 235-238.

Krishna Reddy, S.V., Ksturi Krishna, S., Prasad Rao, J.A.V., Harishu kumar, P. and Krishnamurthy, V. (2007). Effect of application of bio-fertilizers to soybean (Glycine max (L) Merrill) and nitrogen to tobacco (Nicotiana tabacum) in soybean-tobacco cropping system. Indian J. Agron., 52 (4):294299.

Kumrawat, B., Dighe, J.M., Sharma, A.R. and Katti, G.V. (1997). Response of soybean to biofertilizers in black clay soils. Crop Res., 14(2): 209-214.

Oad, F.C., Kumar, L. and Biswas, J.K. (2002). Effect of Rhizobium japonicum inoculum doses (liquid culture) on the growth and seed yield of soybean crop. Asian J. Plant Sci., 1 (4):340-342.

Pratibha Sahai and Ramesh Chandra (2011). Performance of liquid and carrier-based inoculats of Mesorhizobium ciceri and PGPR (Pseudomonas diminuta) in Chickpea (Cicer arietinum L.) on nodulation yield and soil properties. $J$. Indian Soc. Soil Sci. 59 (3): 263-267.

Purbey, S.K. and Sen, N.L. (2007). Effect of bioinoculants and bioregulators on yield and nutrient uptake by fenugreek. Indian J. Agric. Res., 41 (2): 154-156.

Sharma, K.N. and Namdeo (1999). Effect of biofertilizers and phosphorus on growth and yield of soybean, J. Crop Res. 17 (2): 160-163.

Sheerin, S.R., Tamizhvendan, R. and Sundaram, M.D. (1998).Response of Bradyrhizobium japonicum and phosphobacteria for soybean. Madras Agric. J., 85(10): 620-624.

Thenua, O.V.S., Shivakumar, B.G. and Jitendra kumar, M. (2006). Effect of biofertilizers and phosphorous fertilization on nodulation pattern productivity and phosphorous uptake by summer mung (Vigna radiata). Biofertilizer Newsletter, 14 (2): 0.

Tomar, R.K.S. (2011). Effect of integration of bio-fertilizers and farm yard manure with inorganic fertilizers on productivity of soybean (Glycine max) in farmers' fields. J. Oilseed Res., 28 (20): 112-114.

Zarrin fathima, Muhammad Zia and Fayyaz choudary, M. (2007). Interactive effect of Rhizobium strains and $\mathrm{P}$ on soybean yield, Nitrogen fixation and soil fertility. Pakistan. J. Bot., 39 (1): 255264. 


\section{How to cite this article:}

Daravath Raja and Takankhar V. G. 2018. Nutrient Uptake of Soybean (Glycine max L.) Plant as Affected by Liquid Biofertilizers (Bradyrhizobium and PSB). Int.J.Curr.Microbiol.App.Sci. 7(05): 3707-3717. doi: https://doi.org/10.20546/ijcmas.2018.705.429 